\title{
Segmental Specificity of Neuronal Recognition during Synapse Formation between Identified Leech Neurons
}

\author{
David C. Merz and Pierre Drapeau \\ Departments of Biology and Neurology and Neurosurgery, McGill University and Centre for Research in Neuroscience, \\ Montreal General Hospital Research Institute, Montreal, Quebec, Canada H3G 1A4
}

\begin{abstract}
An early event in the formation of inhibitory synapses between the serotonergic Retzius $(R)$ neuron and the pressuresensitive ( $P$ ) neuron of the leech is the elimination of an extrasynaptic, depolarizing response to $5-\mathrm{HT}$ in the $\mathrm{P}$ cell from sites of contact. This effect is induced specifically by contact with the $\mathbf{R}$ neuron but not with other identified leech neurons, including other serotonergic neurons that do not form chemical synapses with the $P$ cell. In the reproductive (fifth and sixth) segmental ganglia, the $R$ cells $\left(R_{(5,6)}\right)$ exhibit functional and morphological differences with the standard $R$ cells $\left(R_{(x)}\right)$ in the other 19 segmental ganglia. In the study presented here, we tested the specificity of $P$ cell recognition of $R$ cells by examining whether there were differences between the $R_{(x)}$ and $R_{(5,6)}$ cells with respect to synapse formation with the $P$ cell.
\end{abstract}

$\mathbf{R}_{(5,6)}$ neurons did not innervate $P$ cells in the fifth and sixth ganglia $\left(P_{(5,6)}\right)$ in vivo or in vitro, nor did they form synapses with $P$ cells from standard ganglia $\left(P_{(x)}\right)$ in vitro except on rare occasions, after long periods in culture. In contrast to the effects of $R_{(5,6)}$ neurons, $R_{(x)}$ neurons readily innervated both $P_{(x)}$ and $P_{(5,6)}$ cells in vitro, suggesting that the lack of an $R_{(5,6)}-P_{(5,6)}$ synapse reflects differences in the presynaptic rather than the postsynaptic cell. In contrast to the $\mathbf{R}_{(\mathbf{x})}$ cell, contact with the $R_{(5,6)}$ neurons had no significant effect on the responses of the $P$ cell to 5-HT. We conclude that the $P$ cell is able to distinguish between the $R_{(x)}$ and $R_{(5,6)}$ neurons through cell surface cues, and that the selection of transmitter responses in the postsynaptic neuron is an early event during neuronal recognition and synapse formation.

[Key words: synapse formation, identified neurons, neuronal recognition, leech CNS, 5-HT, tissue culture]

The guidance of growing axons to their correct target regions occurs through molecular cues present on cells or in the extracellular environment. In simpler nervous systems, cell recognition during axon path formation has been well studied and is believed to occur through the expression of ccll surfacc molccules that identify different neurons (Grenningloh et al., 1992; Leung-Hagesteijn et al., 1992). Isolated neurons from the leech (Ready and Nicholls, 1979), and from the mollusks Aplysia

\footnotetext{
Received Oct. 7, 1993; revised Nov. 19, 1993; accepted Dec. 21, 1993.

This work was supported by an MRC of Canada studentship (D.C.M.) and an award from the FRS of Quebec and grants from the FCAR and MRC of Canada (P.D.). We thank Dr. W. B. Kristan, Jr. for his criticisms of the manuscript.

Correspondence should be addressed to Dr. Pierre Drapeau, Department of Neurology, Montreal General Hospital, 1650 Cedar Avenue, Montreal, Quebec, Canada H3G $1 \mathrm{~A} 4$
}

Copyright (C) 1994 Society for Neuroscience $0270-6474 / 94 / 144125-05 \$ 05.00 / 0$
(Camardo and Proshansky, 1983) and Helisoma (Hadley et al., 1983) form synapses selectively in vitro. Because the choice of synaptic partners occurs in the absence of normal substrates and non-neuronal cells, recognition must depend upon direct interactions betwecn the neurons.

The most extensively studied synapse that is reformed between cultured leech neurons is the chemical connection between the serotonergic Retzius ( $R$ ) neuron and the pressuresensitive mechanosensory (P) neuron. At this synapse both in vivo (Fuchs et al., 1982) and in vitro (Drapeau and SanchezArmass, 1988), the release of serotonin (5-HT) by the R cell activates an inhibitory chloride conductance in the $\mathrm{P}$ cell. Furthermore, synapses between these neurons are observed in the electron microscope, and activity-dependent recycling of synaptic vesicles has been documented (Kuffler et al., 1987). In vitro, the $\mathrm{R}$ cell is always presynaptic to the $\mathrm{P}$ cell, and electrical connections do not form (Fuchs et al., 1982). An early event preceding the formation of the inhibitory R-P synapse is the elimination in the $\mathrm{P}$ cell of an extrasynaptic, depolarizing response to 5-HT (Drapeau and Sanchez-Armass, 1988). The depolarizing response is obscrved in vivo on the $P$ ccll soma, distant from synaptic sites in the neuropil (Sargent et al., 1977; Henderson, 1983), and may be involved in the response of the $P$ cell to 5-HT released nonsynaptically, for example, into the bloodstream, where it acts as a neuromodulator (Kristan and Nusbaum, 1982).

The loss of the depolarizing response is triggered locally by contact with the $\mathrm{R}$ neuron (Drapeau el al., 1989), and results from the loss of sensitivity of cationic channels to activation by 5-HT (Drapeau, 1990; Catarsi and Drapeau, 1992, 1993). This event is cell specific in that contact with identified neurons other than the $\mathrm{R}$ cell, including the serotonergic VL and DL neurons that do not form chemical synapses with the $\mathrm{P}$ cell (Acklin and Nicholls, 1990), has no effect on the P cell responses to 5-HT (Merz and Drapeau, 1992). The specificity of this interaction parallels that of synapse formation, in that the only neuron that induces the loss of the nonsynaptic response is also the only neuron that forms a serotonergic synapse with the $\mathrm{P}$ cell. It therefore appears that the selection of transmitter responses is an early event during neuronal recognition and formation of the R-P synapse (Drapeau and Sanchez-Armass, 1989).

While comparisons of the $\mathrm{R}$ cell with other serotonergic neurons revealed the selectivity in these cellular interactions, a stricter test may be provided by the $R$ cells of the fifth and sixth segmental ganglia, $\mathrm{R}_{(5.6)}$, which are specialized to innervate the reproductive organs. The $\mathrm{R}_{(5.6)}$ neurons are similar to the standard $R$ neurons $\left(R_{(x)}\right)$ in their positions in the ganglia, action potential waveforms, basic branching patterns in the neuropil, 
A B
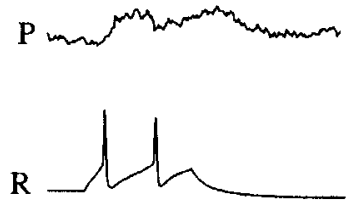

\section{$0.2 \mathrm{mV}$ \\ $30 \mathrm{mV}$ \\ $100 \mathrm{~ms}$}

Figure 1. The R-P synapse is observed in standard but not in reproductive ganglia. Intracellular recording showed synaptic responses of $\mathrm{P}$ cells to $\mathbf{R}$ cell action potentials in five of nine standard ganglia $(A)$ and in zero of nine reproductive ganglia $(B)$. Electrodes $(4 \mathrm{M} \mathrm{KCl}$ ) were used in the $\mathrm{P}$ cell to reverse the chloride gradient, making the synaptic response of the $P$ cell excitatory. Because of the high level of spontaneous chloride-dependent responses in the P cell, averages of 16 sweeps were used to record $\mathrm{R}$ cell-evoked responses.

and content of 5-H'l (Jellies et al., 1987). However, $\mathbf{R}_{(5,6)}$ neurons exhibit several morphological and functional distinctions from $\mathrm{R}_{(\mathrm{x})}$ neurons (Locr and Kristan, 1989; French and Kristan, 1992), including peripheral branches that innervate the reproductive organs and altered synaptic connectivity (Wittenberg et al., 1990). In this report we demonstrate that the $\mathrm{R}_{(5,6)}$ cells are also distinct from $R_{(x)}$ cells in that they neither form synapses with nor affect 5 -HT responses in the $P$ cell. We propose that the $P$ cell is able to recognize $\mathrm{R}$ cells using cell surface cues.

\section{Materials and Methods}

Dissections. Adult Hirudo medicinalis, purchased from Ricarimpex (Audenge, France), were dissected as previously described (Dietzel et al., 1986). Segmental ganglia were removed and pinned in Sylgard-coated dishes. To isolate identified neurons for cell culture, ganglia were desheathed with forceps and exposed to collagenase (type XI, Sigma, St. Louis, MO) for $1 \mathrm{hr}$. Cell bodies were then removed by aspiration with a micropipette. The $\mathrm{R}$ and $\mathrm{P}$ neurons are identifiable by their characteristic sizes and positions in the ganglia. Cell bodies were plated in juxtaposition in Nunclon (Denmark) microtest wells $(10 \mu \mathrm{l})$ coated with poly-L-lysine and cultured at $18^{\circ} \mathrm{C}$ in Liebovitz-15(L-15) medium supplemented with $2 \%$ (by volume) heat-inactivated fetal calf serum (GIBCO Canada, Burlington, Ontario, Canada) and $0.4 \mathrm{mg} / \mathrm{ml}$ gentamicin.

Recordings. Electrophysiological recordings were made with an Axoclamp 2A amplifier (Axon Instruments, Burlingame, CA). Electrodes (15-20 M $)$ ) were filled with $4 \mathrm{M} \mathrm{KCl}, 4 \mathrm{M} \mathrm{K}$-acetate, or $4 \mathrm{M}$ Cs-acetate, as indicated. The responses of isolated $\mathrm{P}$ cells to 5-HT were measured by single electrode voltage clamp in superfusion solutions that allowed the isolation of the cationic and the chloride responses (Drapeau and Sanchez-Armass, 1988). Cationic responses were recorded in $\mathrm{Na}_{2} \mathrm{SO}_{4}$ solution containing (mM) $\mathrm{Na}_{2} \mathrm{SO}_{4}, 135 ; \mathrm{MgSO}_{4}, 5 ; 3,4$-diaminopyridine (DAP; a potassium channel blocker), 10; glucose, 10; HEPES, 10; anthracene-9-carboxylic acid (9-AC; a chloride channel blocker), $0.1 \mathrm{~mm}$ from a $0.4 \mathrm{M}$ stock dissolved in dimethyl sulfoxide (DMSO). The 9-AC stock solution in DMSO was diluted to a final concentration of $0.05 \%$ (by volume); this low concentration of DMSO had no effect on the cells. Chloride responses were recorded in Tris-Cl solution containing (mM) Tris $\mathrm{Cl}, 165 ; \mathrm{CsCl}, 5 ; \mathrm{MgCl}_{2}, 5 ; \mathrm{DAP}, 10 ;$ glucose, 10 . The 5-HT (100 $\mu \mathrm{M}$ dissolved in the superfusion solution) was applied by pressure (200 msec at 1 bar) from a pipette with a $15-20 \mu \mathrm{m}$ opening, and gave a maximal response (Drapeau and Sanchez-Armass, 1988). Recordings from leech ganglia were performed in Ringer's solution containing (mM) $\mathrm{NaCl}, 115 ; \mathrm{KCl}, 4 ; \mathrm{CaCl}_{2}, 1.8$; Tris, $10 ;$ mleate, $10 ; \mathrm{pH}$ 7.4. Recordings of synaptic connections between pairs of cultured neurons were done in $\mathrm{L}-15$ culture medium. The signals were filtered $(-3 \mathrm{~dB}$ at $1 \mathrm{kHz})$, digitized $(1 \mathrm{kHz})$ using a TL-1 interface, and analyzed using pcLAmP software from Axon Instruments (Burlingame, CA).

\section{Results}

\section{Synapses}

Ihe inhibitory synapse between the $\mathrm{R}$ and $\mathrm{P}$ cells in standard segmental ganglia, which shows a chloride-dependent response, is often difficult to detect when cliciting single impulses (Fuchs et al., 1982). This is due to a combination of factors that include the remoteness of the cell body from the synaptic sites in the neuropil, the fact that the chloride reversal potential is near the resting potential, and the high frequency of larger, spontaneous chloride-dependent inputs from unknown sources. When a $\mathrm{KCl}$ electrode was used to penetrate the $\mathrm{P}_{(x)}$ cell to reverse the chloride gradient, action potentials in the $\mathrm{R}_{(\mathrm{x})}$ cell revealed a small averaged postsynaptic depolarization with a brief delay and with an amplitude greater than the residual noise in five of nine cell pairs in standard ganglia (Fig. 1). This response was easier to detect in $\mathrm{P}_{(x)}$ cells showing fewer spontaneous synaptic potentials. Stimulation of the $\mathrm{R}_{(5.6)}$ neurons in reproductive ganglia did not produce a detectable response in $\mathrm{P}_{(5,6)}$ cells $(n=9$; Fig. 1). Thus, there does not appear to be a functional connection between the $R_{(5,6)}$ and $P_{(5,6)}$ neurons of the reproductive ganglia $\left(\chi^{2}, p<0.01\right)$. This may be the result of differences between the $\mathrm{R}_{(\mathrm{x})}$ and the $\mathrm{R}_{(5,6)}$ cells, which have previously been shown to have distinct synaptic connections (Wittenberg et al., 1990) or, alternatively, these cells may not come into contact during development. To investigate the ability of the $R_{(5,6)}$ neurons to form synapses with the $\mathrm{P}_{(x)}$ and $\mathrm{P}_{(5,6)}$ cells, cell somas were isolated and paired in culture.

In vitro, the $\mathrm{R}_{(\mathrm{x})}-\mathrm{P}_{(\mathrm{x})}$ synapse reformed reliably when the cell somas were plated in contact with one another. The $R_{(x)}$ cell was always presynaptic, and the response in the $P_{(x)}$ cell was chloride dependent, with a reversal potential near the resting potential of $-50 \mathrm{mV}$ (Drapeau and Sanchez-Armass, 1988). After 4 to $12 \mathrm{~d}$ in culture, $50 \%$ (27 of 54) of $\mathrm{R}_{(\mathrm{x})}-\mathrm{P}_{(\mathrm{x})}$ pairs formed synapses with a chloride-dependent response (Fig. $2 A$ ). The $\mathrm{R}_{(\mathrm{x})}$ neurons formed similar synapses with the $\mathrm{P}_{(5,6)}$ neurons in about half $(8$ of 17) of the pairs with culture periods of 4-11 d (Fig. 2B). In contrast, no synaptic responses were observed between 19 pairs of $\mathrm{R}_{(5.6)}$ and $\mathrm{P}_{(5.6)}$ neurons with culture periods of up to $12 \mathrm{~d}$ (Fig. $3 A)$. Synapses between $\mathrm{R}_{(5.6)}$ neurons and $\mathrm{P}_{(\mathrm{x})}$ cells occurred only rarely ( 3 of 62 cell pairs; Fig. $3 B$ ) and the responses were chloride dependent, with no synaptic responses recorded with culture periods of less than $10 \mathrm{~d}$, suggesting that the occasional $R_{(5.6)}$ neuron may regain the ability to innervate $P$ cells but only after prolonged periods in culture. Synaptic responses in pairs of $R_{(5,6)}$ neurons were readily detected after $4 \mathrm{~d}$ in culture ( 4 of 11 cell pairs), suggesting that the $R_{(5,6)}$ neuron is capable of forming synapses in vitro, although not with the $\mathrm{P}$ cell.

These results show that the $R_{(5,6)}$ have a greatly reduced ability to form synapses with the $P$ neuron, whereas $P_{(5,6)}$ cells are indistinguishable from $P_{(x)}$ neurons in their ability to be innervated by the $R_{(x)}$ cells. Thus, the apparent failure of $R_{(5,6)}$ neurons to innervate $P_{(5,6)}$ neurons in vivo is likely due to an inability of the $R_{(5.6)}$ neurons to form synapses and is independent of the segmental origin of the isolated $P$ cells, although we have not examined if synaptic structures such as those seen between $R_{(x)}$ and $P_{(x)}$ cells (Kuffler et al., 1987) fail to form between neurons from ganglia 5 and 6 . 
A

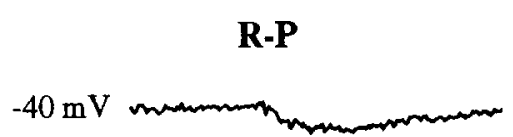

$-50 \mathrm{mV}$

$-75 \mathrm{mV}$

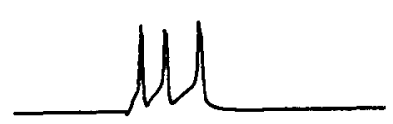

$5 \mathrm{mV}$
$50 \mathrm{mV}$$\bigsqcup_{200 \mathrm{~ms}}$
B
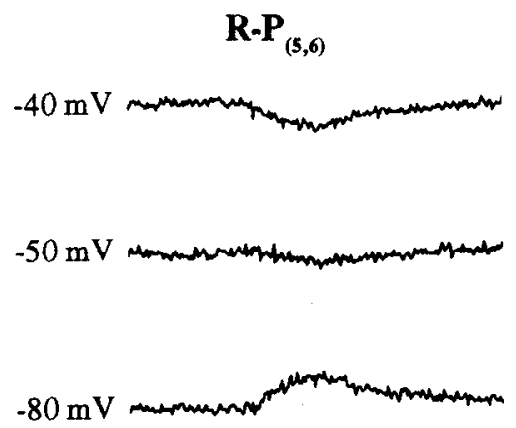

Figure 2. Standard $\mathrm{R}$ cells innervate $P$ cells from either standard or reproductive ganglia in vitro. Intracellular recordings from pairs of cells were performed in L-15 culture medium using electrodes filled with $4 \mathrm{M} \mathrm{K}$-acetate (in some cases, Cs-acetate electrodes were used to broaden the action potential of the $\mathrm{R}$ cell). $A, \mathrm{R}_{(\mathrm{x})}-\mathrm{P}_{(\mathrm{x})}$ synapses formed between 27 of 54 pairs with reversal potentials of about $-55 \mathrm{mV}$, near the chloride reversal potential. $B, \mathrm{R}_{(\mathrm{x})}$ cells formed similar synapses with $P_{(5.6)}$ cells in 8 of 7 pairs.

\section{Loss of the extrasynaptic response}

The contact-mediated loss of the cationic response to 5-HT in the $P$ cell is thought to be an early step in the formation of an inhibitory R-P synapse. This effect is not elicited by neurons other than the R cell (Merz and Drapeau, 1992), and therefore provides a sensitive test of cell recognition between the $R$ cell and $P$ cells. To test whether the nonsynaptic $R_{(5,6)}$ was capable of eliciting this effect in the $P$ cell, we examined the 5-HT responses of $\mathrm{P}$ cells cocultured with $\mathrm{R}_{(5.6)}$ cells.

The responses of the $\mathrm{P}$ cells to pipette-applied 5-HT were recorded after $5 \mathrm{~d}$ in culture (Fig. 4). Single $\mathrm{P}$ cells had cation conductances of $4.0 \pm 0.3 \mathrm{nS}(n=70)$ in $\mathrm{Na}_{2} \mathrm{SO}_{4}$ solution (Fig. $4 A, B)$, while those paired in contact with $\mathrm{R}_{(\mathrm{x})}$ neurons were significantly less $(1.8 \pm 0.3 \mathrm{nS} ; n=33$; Student's $T$ test, $p<$ $0.01)$. In contrast, contact with the $\mathrm{R}_{(5.6)}$ neuron did not produce a significant reduction in the amplitude of the cationic response $(3.7 \pm 0.4 \mathrm{nS} ; n=15)$. The $\mathrm{R}_{(5,6)}$ cell soma is smaller than that of the $\mathrm{R}_{(\mathrm{x})}$ cell, but pairing the $\mathrm{P}$ cell with two $\mathrm{R}_{(0,6)}$ cells similarly did not have an effect $(n=4)$, ruling out an artifact due to differences in cell size or area of surface contact. There was no significant difference in the chloride conductances recorded in
A
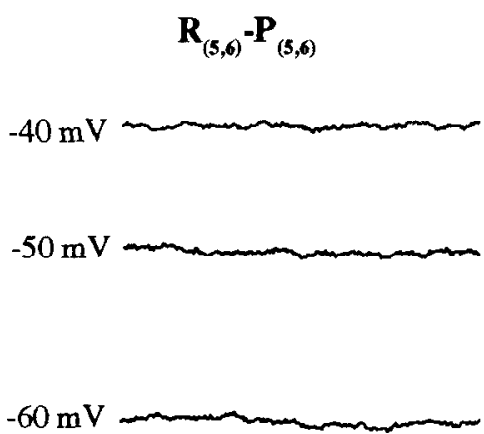

B
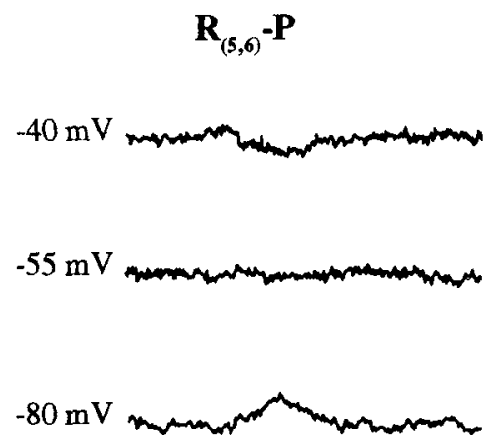
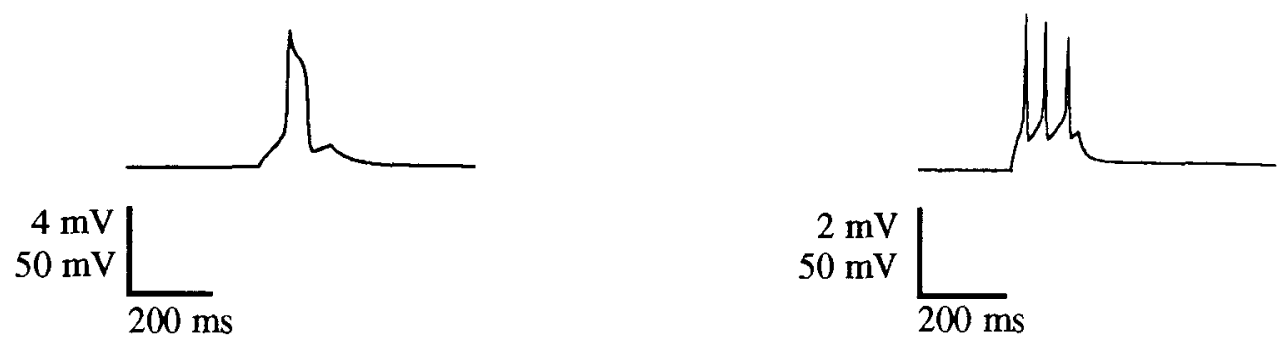

Figure 3. $\mathbf{R}_{(5.6)}$ cells innervate $\mathbf{P}$ cells rarely, and only after long periods in culture. $\mathbf{R}_{(5.6)}$ cells did not form synapses with $\mathbf{P}_{(0.0)}$ cells in 19 pairs, even when the action potential was prolonged by using a Cs-acetate electrode $(A)$. Synapses between $\mathrm{R}_{(5,6)}$ cells and $\mathrm{P}_{(x)}$ cells were observed in only 3 of 62 pairs, and only after 10 or more days in culture $(B)$. These synapses had reversal potentials near the chloride reversal potential of $-55 \mathrm{mV}$. 
$\mathbf{A}$

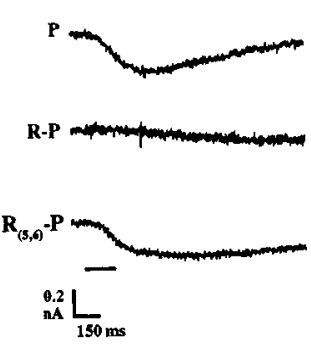

B

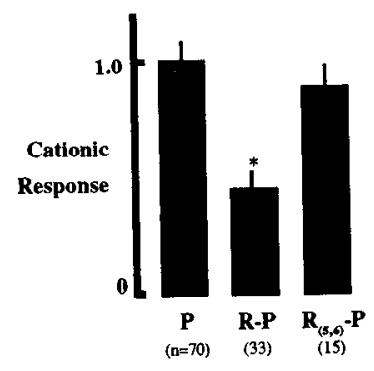

C

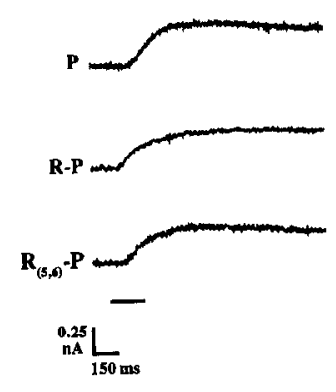

D

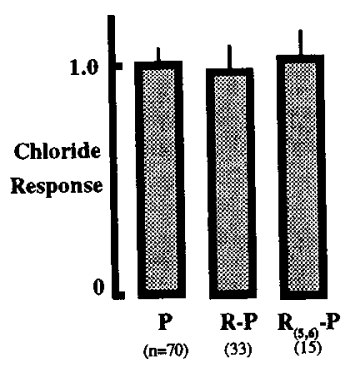

Figure 4. Contact with the $\mathrm{R}_{(\mathrm{x})}$ cell but not with the $\mathrm{R}_{(5,6)}$ cell causes a selective reduction in the cationic response to 5-HT in the $\mathrm{P}$ cell. $A$ and $B$, Cationic responses of voltage clamped $\mathrm{P}_{(\mathrm{x})}$ cells to pipette-applied 5-HT were reduced by more than $50 \%$ by contact with $R_{(x)}$ cells. Traces in $A$ were recorded at $-45 \mathrm{mV}$ in $\mathrm{Na}_{2} \mathrm{SO}_{4}$ solution, and 5 -HT was applied during the period indicated by the bar below the bottom trace. $B$, Mean cationic conductances elicited by 5 -HT plus standard crrors normalized to controls (single P cells; $4.0 \pm 0.3 \mathrm{nS}$ ) are shown. The asterisk indicates statistical significance at the $p<0.05$ level. $C$ and $D$, Chloride responses were unaffected by contact with $\mathrm{R}$ or $\mathrm{R}_{(5,8)}$ cells. $C$, Chloride currents were recorded in Tris-Cl solution at $0 \mathrm{mV}$. $D$, Mean plus standard error chloride conductances normalized to control values $(9.2 \pm 0.6 \mathrm{nS})$.

Tris-Cl solution for any cell pairing (Fig. $4 C, D$ ), suggesting that the $R_{(x)}$ cell selectively reduced the cationic response in the $P$ cell.

\section{Discussion}

The mechanism by which neurons can discriminate between correct and incorrect synaptic partners has been a subject of great interest, particularly since the chemoaffinity hypothesis of Sperry (1963), which postulated the existence of identifying molecules that permit neurons to recognize one another. In mammals, neurons establish their mature patterns of connectivity by recognizing correct targets during the initial formation of synapses, then allowing activity-dependent modulation of excitatory synaptic strengths (Constantine-Paton et al., 1990; Shatz, 1991). In contrast, little is known about the formation of inhibitory connections. In the simpler nervous systems of invertebrates, where fewer cells must connect appropriately, the role of activity-dependent processes is less obvious, and neuronal recognition may be sufficient to establish the patterns of synaptic connectivity (Goodman et al., 1984; Nicholls, 1987). Because synapse formation can be studied in fine detail in these systems, invertebrates provide a useful model for studying the mechanism of ncuronal rccognition.

In standard segmental ganglia, the inhibitory R-P synapse may provide feedback modulation of $P$ cell activity, as action potentials in the $P$ cell elicit strong excitatory potentials in the $R$ cell via a polysynaptic connection (Wittenburg et al., 1990).

'The $\mathrm{K}_{(5.6)}$ cells retain most of the characteristics of $\mathrm{R}_{(\mathrm{x})}$ neurons, including their basic branching patterns in the neuropil, 5-HT content, and clectrical propertics. However, the $R_{(5.6)}$ cells innervate the reproductive organs of the leech rather than the body wall, and their morphological and functional differences with the $R_{(x)}$ cells are induced by the reproductive organs themselves (Loer and Kristan, 1989). In contrast to the excitatory $P$ to $R$ connections, the $P_{(5.6)}-R_{(5.6)}$ connection, when present, is inhibitory (Wittenberg et al., 1990), and as shown in this report, there is no $R_{(5.6)}-P_{(5,6)}$ connection. Thus, in the reproductive ganglia, the circuits and connections linking $R$ and $P$ cells appear to be altered or missing. These differences may reflect the altered functional role of the $\mathrm{R}_{(5,6)}$ cells, which, unlike the $\mathrm{R}_{(x)}$ cell, are not involved in behaviors such as swimming (Loer and Kristan, 1989).

The absence of an $R_{(5,6)}-P_{(5,6)}$ synapse could result from differences of either cell type from those of standard ganglia. However, isolated $P_{(5,6)}$ cells were innervated by $R_{(x)}$ cells, and these synapses were indistinguishable from those with $P_{(x)}$ cells. $R_{(5.6)}$ synapses with $\mathrm{P}_{(\mathrm{x})}$ cells, on the other hand, were observed only rarely and only after long periods in culture. Hence, the $R_{(5.6)}$ cells may have a limited ability to synapse onto the $\mathbf{P}$ cell, or alternatively, there may be changes in the cells as a result of long periods in culture. These observations suggest that the absence of this synapse in the reproductive ganglia in vivo may be due to an inability of the $R_{(5,6)}$ cell to innervate $P$ cells during development of the nervous system.

The loss of the extrasynaptic, depolarizing response to 5-HT from sites of contact with the $\mathrm{R}$ cell is an early step in the formation of the inhibitory R-P synapse (Drapeau and SanchezArmass, 1989). It was previously reported that when $P$ cells were contacted by leech neurons other than the $\mathrm{R}$ neuron, they retained the cationic response to 5-HT. The ineffective cells included sensory neurons, postsynaptic motor neurons, presynaptic interneurons, and the nonsynaptic VL and DL serotonergic neurons (Merz and Drapeau, 1992). The evidence presented in this report extends this specificity to a subtype of $\mathrm{R}$ neurons by demonstrating that despite their many similarities to $R_{(x)}$ cells, the $R_{(5.6)}$ cells neither innervated $P$ cells nor affected their responses to 5-HT.

Previous work has shown that aldehyde-fixed $R$ cells retain the ability to reduce the extrasynaptic response in $\mathrm{P}$ cells cultured in close contact (Drapeau et al., 1989). Treatment of the $\mathrm{R}$ cell with trypsin or with the lectin wheat germ agglutinin (but not other lectins) prior to fixation prevents the loss of the extrasynaptic response in the P cell (Merz and Drapeau, 1991), demonstrating that $\mathrm{R}$ cell surface contact is required, possibly mediated by an $\mathrm{R}$ cell-specific surface glycoprotein. The expression of surface molecules specific to individual cell types or subsets of neurons has been previously described in the leech (Zipser and McKay, 1981), and in other invertebrates (Fujita et al., 1982; Chang et al., 1983; Kotrla and Goodman, 1984; Denburg et al., 1986; Meier et al., 1993). Thus, it seems probable that the $R$ neuron expresses a surface molecule that is not expressed on the $\mathrm{R}_{(5.6)}$ cell.

The postsynaptic effects of contact with the $R$ cell involve the loss of modulation of cation channels by protein kinase C (Drapeau, 1990; Catarsi and Drapeau, 1992). This change in sensitivity of the cation channels can be blocked by inhibitors of protein tyrosine kinases (Catarsi and Drapeau, 1993), suggesting a role for these molecular signals of cellular differentiation in synapse formation. Thus, cell recognition in this system may 
result from the activation by an $\mathrm{R}_{(x)}$ cell-specific molecule of a tyrosine kinase in the $\mathrm{P}$ cell, reminiscent of the cellular interactions during differentiation of the Drosophila eye (Rubin, 1991). The early loss of the extrasynaptic response during formation of the inhibitory R-P synapse suggests that, in contrast to activity-dependent strengthening of excitatory connections, cell contact is more critical for establishing inhibitory synapses.

Molecular genetic studies in Drosophila and Caenorhabditis elegans suggest that cell identity can be regulated at many different levels. For example, the $f t z$ and eve mutations in Drosophila cause complete shifts in cell fates (Doe et al., 1988a,b). In contrast, the loss of function of the unc- 4 homeodomain protein in C. elegans has a more limited effect. Unc-4 mutations to a set of ventral motor neurons alter their inputs yet have no effects on their morphology or outputs (Miller et al., 1992; White et al., 1992). The specializations that arise during development in the $\mathrm{R}_{(5.6)}$ cells may similarly represent the altered expression of a small number of genes. This raises the possibility that the $\mathbf{R}_{(5.6)}$ cell may prove useful in identifying the molecular interactions underlying neuronal recognition during synapse formation

\section{References}

Acklin SE, Nicholls JG (1990) Intrinsic and extrinsic factors influencing properties and growth patterns of identified leech neurons in culture. J Neurosci 10:1082-1090.

Camardo J, Proshansky E, Schacher S (1983) Identified Aplysia neurons form specific chemical synapses in culture. J Neurosci 3:26142620.

Catarsi S, Drapeau P (1992) Loss of extrasynaptic channel modulation by protein kinase $\mathrm{C}$ underlies the selection of serotonin responses in an identified leech neuron. Neuron 8:275-281.

Catarsi S, Drapeau P (1993) Tyrosine kinase-dependent selection of transmitter responses induced by neuronal contact. Nature 363:353355.

Chang S, Ho RK, Goodman CS (1983) Selective groups of neuronal and mesodermal cells recognized early in grasshopper embryogenesis by a monoclonal antibody. Dev Brain Res 9:297-304.

Constantine-Paton M, Cline HT, Debski E (1990) Patterned activity, synaptic convergence, and the NMDA receptor in developing visual pathways. Annu Rev Neurosci 13:129-154.

Denburg JL, Caldwell RT, Marner JM (1986) Monoclonal antibodies to the cockroach nervous system. J Comp Neurol 245:123-136.

Dietzel ID, Drapeau P, Nicholls JG (1986) Voltage-dependence of 5 -hydroxytryptamine release at a synapse between identified leech neurones in culture. J Physiol (Lond) 372:191-205.

Doe CQ, Hiromi Y, Gehring WJ, Goodman CS (1988a) Expression and function of the segmentation gene fushi tarazu during Drosophila neurogenesis. Science 239:170-175.

Doe CQ, Smouse D, Goodman CS (1988b) Control of neuronal fate by the Drosophila segmentation gene even-skipped. Nature 333:376378.

Drapeau P (1990) Loss of channel modulation by transmitter and protein kinase $C$ during reinnervation of an identified leech neuron. Neuron 4:875-882.

Drapeau P, Sanchez-Armass S (1988) Selection of postsynaptic serotonin receptors during reinnervation of an identified leech neuron in culture. J Neurosci 8:4718-4727.

Drapeau P, Sanchez-Armass S (1989) Parallel processing and selection of the responses to serotonin during reinnervation of an identified leech neuron. J Neurobiol 20:312-325.

Drapeau P, Melinyshyn E, Sanchez-Armass S (1989) Contact-mediated loss of the nonsynaptic response to transmitter during reinnervation of an identified leech neuron in culture. J Neurosci 9:25022508.

French KA, Kristan WB Jr (1992) Target influences on the development of leech neurons. Trends Neurosci 15:169-174.

Fuchs PA, Henderson LP, Nicholls IG (1982) Chemical transmission between individual Retzius and sensory neurons of the leech in culture. J Physiol (Lond) 323:195-210.
Fujita SC, Zipursky S, Benzer S, Ferrus A, Shotwell SL (1982) Monoclonal antibodies against the Drosophila nervous system. Proc Natl Acad Sci USA 79:7929-7933.

Goodman CS, Bastiani MJ, Doe CQ, Du Lac S, Helfand SL, Kuwada JY, Thomas JB (1984) Cell recognition during neuronal development. Science 225:1271-1276

Grenningloh G, Bieber A, Rehm J, Snow PM, Traquina Z, Hortsch M, Patel NH, Goodman CS (1992) Molecular genetics of neuronal recognition in Drosophila: evolution and function of immunoglobulin superfamily cell adhesion molecules. Cold Spring Harbor Symp Quant Biol 55:327-340.

Hadley RD, Kater SB, Cohan CS (1983) Electrical synapse formation depends on interaction of mutually growing neurites. Science 221: $466-468$.

Henderson LP (1983) The role of 5-hydroxytryptamine as a transmitter between identified leech neurones in culture. J Physiol (Lond) 339:309-324

Jellies J, Loer CM, Kristan WB Jr (1987) Morphological changes in leech Retzius neurons after target contact during embryogenesis. J Neurosci 7:2618-2629.

Kotrla KJ, Goodman CS (1984) Transient expression of a surface antigen on a small subset of neurones during embryonic development. Nature 311:151-153.

Kristan WB, Nusbaum MP (1982) The dual role of serotonin in leech swimming. J Physiol (Paris) 78:743-747.

Kuffler DK, Nicholls JG, Drapeau P (1987) Transmitter localization and vesicle turnover at a serotonergic synapse between identified leech neurons in culture. $\mathrm{J}$ Comp Neurol 256:516-526.

Leung-Hagesteijn C, Spence AM, Stern BD, Zhou Y, Su M-W, Hedgecock EM, Culotti JG (1992) UNC-5, a transmembrane protein with immunoglobulin and thrombospondin type 1 domains, guides cell and pioneer axon migrations in C. elegans. Cell 71:289-299.

Loer CM, Kristan WB Jr (1989) Central synaptic inputs to identified leech neurons determined by peripheral targets. Science 244:64-66.

Meier T, Therianos S, Zacharias D, Reichert H (1993) Developmental expression of TERM-1 glycoprotein on growth cones and terminal arbors of individual identificd ncurons in the grasshoppcr. J Ncurosci 13:1498-1510.

Merz DC, Drapeau P (1991) Cell-specific surface component selects the response to transmitter during synapse formation between identified leech neurons. Soc Neurosci Abstr 17:295.8.

Merz DC, Drapeau P (1992) Cell-specific contact selects transmitter responses in an identified leech neuron. Proc R Soc Lond [Biol] 248: 129-133.

Miller DM, Shen MM, Shamu CE, Burglin TR, Ruvkun G, Dubois ML, Ghee M, Wilson L (1992) C. elegans unc-4 gene encodes a homeodomain protein that determines the pattern of synaptic input to specific motor neurons. Nature 355:841-845.

Nicholls JG (1987) The search for connections: studies of regeneration in the nervous system of the leech. Magnes Lect Ser 2:1-86.

Rcady DF, Nicholls JG (1979) Identified ncurons isolated from lecch CNS make selective connections in culture. Nature 281:67-68.

Rubin GM (1991) Signal transduction and the fate of the R7 receptor in Drosophila. Trends Genet 7:372-377.

Sanchez-Armass S, Merz DC, Drapeau P (1991) Distinct receptors, second messengers, and conductances underlying the dual responses to serotonin in an identified leech neurone. J Exp Biol 155:531-547.

Sargent PB, Yau KW, Nicholls JG (1977) Extrasynaptic receptors on cell bodies of neurons in central nervous system of the leech. J Neurophysiol 40:446-452.

Schacher S, Rayport SG, Ambron RT (1985) Giant Aplysia neuron R2 reliably forms strong chemical synapses in vitro. J Neurosci 5:28512856.

Shatz CS (1991) Impulse activity and patterning of connections during CNS devclopment. Ncuron 5:745-756.

Sperry RW (1963) Chemoaffinity in the orderly growth of nerve fiber patterns and connections. Proc Natl Acad Sci USA 50:703-710.

White JG, Southgate E, Thomson JN (1992) Mutations in the Caenorhabditis elegans unc- 4 gene alter the synaptic input to ventral cord motor neurons. Nature 355:838-841.

Wittenberg G; Loer CM, Adamo SA, Kristan WB Jr (1990) Segmental specialization of neuronal connectivity in the leech. J Comp Physiol [A] 167:453-459.

Zipser B, McKay R (1981) Monoclonal antibodies distinguish identifiable neurons in the leech. Nature 289:549-554. 